\title{
Peran Preservasi Kuratif Dalam Menjamin Keselamatan Dan Pelestarian Arsip Statis
}

\author{
Rapita \\ Pascasarjana, UIN Sunan Kalijaga Yogyakarta \\ Jl. Laksda Adisucipto, Papringan, Caturtunggal, Kec. Depok, Kabupaten Sleman, Daerah \\ Istimewa Yogyakarta 55281 \\ Email:rapita@gmail.com
}

\begin{abstract}
Introduction. This paper aims to determine the role of curative preservation in ensuring the safety and preservation of static archives. Data Collection Method. The method used in this research is descriptive qualitative with data collection techniques using library studies. Results and Discussions. The results of the study found that curative preservation plays a very important role in ensuring the safety and preservation of archives because the actions and instructions contained in it can repair and maintain archives that have started or have been damaged. So that these actions and instructions can be used as guidelines by any archival institution to repair and maintain the static archives they have.
\end{abstract}

Keywords: curative preservation, archive safety and preservation, archives

\begin{abstract}
ABSTRAK
Pendahuluan. Tulisan ini bertujuan untuk mengetahui peran preservasi kuratif dalam menjamin keselamatan dan pelestarian arsip statis. Metode Penelitian. Metode yang digunakan dalam penelitian ini adalah kualitatif deskriptif dengan teknik pengumpulan data menggunakan studi pustaka. Hasil dan Pembahasan. Hasil penelitian didapatkan bahwa preservasi kuratif sangat berperan dalam menjamin keselamatan dan kelestarian arsip karena tindakan-tindakan serta petunjuk-petunjuk yang ada di dalamnya dapat memperbaiki dan merawat arsip yang mulai atau sudah rusak. Sehingga dengan tindakan-tindakan dan petunjuk tersebut dapat dijadikan pedoman oleh Lembaga arsip manapun untuk memperbaiki dan merawat arsip statis yang mereka miliki.
\end{abstract}

Kata Kunci: Preservasi Kuratif, Keselamatan dan Pelestarian arsip, arsip statis

\section{PENDAHULUAN}

Arsip statis adalah arsip yang dihasilkan oleh pencipta arsip karena memiliki nilai guna kesejarahan, telah habis masa retensinya dan berketerangan dipermanenkan yang telah diverifikasi baik secara langsung maupun tidak langsung oleh ANRI dan/Lembaga kearsipan (Indonesia R. , 2009). Arsip statis merupakan muara akhir atau muara dari perjalanan arsip, dimana harus melalui beberapa proses/prosedur yang telah ditentukan sesuai dengan kaidah-kaidah kearsipan yang telah lazimnya disebut pengolahan arsip statis (Arsip Statis, 2021). Pengolahan arsip statis adalah proses 
pengendalian arsip statis secara efisien, efektif, dan sistematis yang meliputi akuisisi, pengolahan, preservasi, pemanfaatan, pendayagunaan, dan pelayanan publik dalam suatu sistem kearsipan nasional (Sattar, 2020).

Secara alami keberadaan media arsip akan mengalami proses pelapukan jika disimpan dalam jangka waktu lama. Kertas sebagai salah satu media perekam informasi arsip merupakan bahan organik yang dapat terurai seiring dengan berjalannya waktu. Demikian pula arsip jenis lainnya seperti arsip foto, film, video, rekaman suara, memiliki resiko kerusakan karena mengandung bahan-bahan yang tidak stabil. Proses pelapukan terhadap media arsip akan terus berjalan dan sering tidak diketahui dan tidak mampu untuk dicegah sampai ditemukan perubahan kepada fisik arsip. Oleh karenanya, upaya yang dapat dilakukan adalah memperlambat dan mengurangi kerusakan yang terjadi serta menjamin arsip tersimpan dalam lingkungan yang aman sehingga arsip dapat mudah diakses (Indonesia R. , 2009). Dalam Perka ANRI Lembaga kearsipan harus mempunyai tugas, fungsi, dan tanggung jawab terhadap pengolahan arsip statis dengan menunjukkan komitmen untuk menjamin keselamatan dan kelestarian arsip statis. Pimpinan Lembaga kearsipan wajib membuktikan komitmennya dalam bentuk kebijakan preservasi arsip statis.

Preservasi ialah merupakan suatu kegiatan yang meliputi pemeliharaan, penyelamatan, dan perawatan yang bertujuan untuk melindungi fisik arsip statis agar tetap awet dan tahan lama sehingga kandungan informasinya dapat terjaga (Sofia Nurani). Preservasi arsip adalah semua aktivitas untuk memperpanjang usia arsip, termasuk kegiatan pemeliharaan dan perawatan arsip (Maziyah, 2005). Preservasi merupakan seluruh kegiatan kerja dalam rangka perlindungan arsip terhadap kerusakan arsip atau unsur perusak arsip untuk menjamin keselamatan dan pelestarian arsip statis tekstual yang dilakukan secara preventif dan kuratif. Tindakan yang dapat dilakukan untuk memperbaiki kerusakan atau merawat arsip yang mulai atau sudah rusak disebut dengan preservasi kuratif. Preservasi kuratif inilah yang akan menjadi bahasan dalam kajian ini. Penulis ingin mengetahui apa yang dimaksud dengan preservasi kuratif, kegiatannya, tujuan, serta perawatan dan perbaikan yang ada dalam preservasi kuratif. 


\section{KAJIAN TEORI}

\section{Pengertian Preservasi Kuratif}

Menurut Perka ANRI Nomor 23 Tahun 2011 tentang Pedoman preservasi Arsip Statis menjelaskan bahwa preservasi kuratif adalah preservasi yang bersifat perbaikan/perawatan terhadap arsip yang mulai/sudah rusak atau kondisinya memburuk, sehingga dapat memperpanjang usia arsip (Sattar, 2020).

\section{Kegiatan Preservasi}

Tindakan preservasi kuratif dilakukan pada arsip statis yang telah mengalami kerusakan dengan cara perbaikan/perawatan. Metode yang digunakan tergantung dari jenis media dan jenis kerusakan yang terjadi pada arsip statis. Untuk melakukan Tindakan preservasi kuratif dibutuhkan ruang dan peralatan serta pendukung lain sesuai dengan jenis arsip statis yang ditangani (Indonesia R. , 2009).

Tindakan kuratif merupakan upaya yang paling efektif dalam mendukung preservasi jangka Panjang arsip statis. Tindakan kuratif dalam konteks preservasi arsip statis dilakukan setelah Tindakan preventif dilakukan secara maksimal. Namun, karena proses pelapukan yang terjadi pada fisik arsip karena factor perusak arsip maka tindakan perbaikan/perawatan arsip statis harus dilakukan.

\section{Tujuan Preservasi Kuratif}

Preservasi kuratif bertujuan untuk melindungi fisik arsip agar tahan lama, menghindarkan kerusakan arsip sehingga kandungan informasinya dapat terjaga selamanya. Tujuan utama preservasi kuratif adalah memperbaiki/merawat arsip yang mulai/sudah rusak dan kondisinya memburuk, sehingga dapat memperpanjang usia arsip statis. Oleh karena itu sangat penting untuk menerapkan konsep Tindakan kuratif dalam kerangka preservasi arsip statis secara menyeluruh (Sattar, 2020).

\section{Prinsip Perbaikan Arsip}

Ada beberapa prinsip perbaikan arsip menurut Perka ANRI Nomor 23 Tahun 2011 dalam Sattar, yaitu:

1) Seluruh proses perbaikan arsip tidak akan menghilangkan, menambah, dan mengubah nilai arsip sebagai alat bukti sehingga keaslian arsip terjaga.

2) Arsip-arsip status harus dijadwalkan untuk dilakukan perbaikan dan perawatan dengan segera setelah terjadi kerusakan 
3) Seluruh proses tidak akan merusak atau melemahkan arsip sehingga aman bagi arsip (reversible)

4) Diupayakan mengganti bahan yang hilang dari arsip menggunakan bahan yang sama atau mirip dengan yang asli

5) Proses perbaikan arsip baik sebelum dan sesudah perbaikan harus didokumentasikan

6) Perbaikan arsip harus dilakukan oleh ahli perbaikan arsip yang terlatih dan memiliki pengetahuan tentang Teknik perbaikan arsip dan kesadaran akan pentingnya memelihara keutuhan suatu arsip tanpa melupakan segi keindahan (Sattar, 2020).

\section{Ruangan Perbaikan Arsip}

Ruangan perbaikan arsip harus memenuhi syarat yaitu sebagai berikut:

1) Terkoneksi langsung dengan depot

2) Memiliki suhu dan kelembaban sesuai dengan persyaratan penyimpanan berdasarkan jenis dan format arsip

3) Memiliki cahaya alami yang bersumber dari jendela, serta memiliki fasilitas air yang baik

4) Ruangan dapat berbentuk persegi dan tidak kurang dari $25 \mathrm{~m}^{2}$ dengan satu sisi berupa jendela

5) Keamanan ruangan harus terjaga karena banyak peralatan dan arsip yang sedang diperbaiki. Ruangan harus dikunci ketika staf ruangan meninggalkan ruangan

6) Akses terhadap ruangan harus diperhatikan yaitu hanya untuk staf dan orangorang yang memiliki izin masuk

7) Ruangan harus dibersihkan secara rutin

\section{METODE PENELITIAN}

Metode yang digunakan dalam penelitian ini adalah metode kualitatif. Metode penelitian kualitatif adalah metode penelitian yang digunakan untuk meneliti pada kondisi obyek yang alamiah dimana peneliti adalah sebagai instrument kunci (Sugiyono, 2016). Adapun pengumpulan data dalam penelitian ini adalah dengan menggunakan teknik studi pustaka (literature review). Studi pustaka adalah teknik pengumpulan data dengan mengadakan studi penelaahan terhadap buku-buku, literatur- 
literatur, catatan-catatan, dan laporan-laporan yang ada hubungannya dengan masalah yang dipecahkan. Studi pustaka merupakan langkah yang penting dimana setelah seorang peneliti menetapkan topik penelitian, langkah selanjutnya adalah melakukan kajian yang berkaitan dengan teori dan yang berkaitan dengan topik penelitian. Dalam pencarian teori, peneliti akan mengumpulkan informasi sebanyak-banyaknya dari kepustakaan yang berhubungan. Sumber-sumber kepustakaan dapat diperoleh dari: buku, jurnal, majalah, hasil-hasil penelitian (tesis dan disertasi), dan sumber-sumber lainnya yang sesuai baik melalui internet, koran dan lain-lain (Nazir, 2014).

\section{PEMBAHASAN}

\section{A. Perawatan Arsip Kertas}

1. Persyaratan Bahan

a. Kertas

1) Kertas harus bebas lignin

2) Mempunyai pH antara 6-8

3) Mempunyai ketahanan sobek yang baik

4) Mempunyai ketahanan lipat yang baik

5) Mempunyai ketebalan dan berat sesuai dengan maksud dan tujuannya

6) Mempunyai ketahanan regang sesuai dengan maksud dan tujuannya

7) Kandungan zat pengisi dalam kertas dibawah 10\%, kandungan yang lebih besar dari $10 \%$ dapat diterima, asalkan kekuatan lipat dan kekuatan sobek memenuhi syarat.

b. Perekat

1) Perekat harus memenuhi $\mathrm{pH}$ antara 6-8

2) Kandungan zat tambahan harus serendah mungkin, bebas dari tembaga, zink klorida dan asam

3) Sebaiknya tidak berwarna

4) Setelah kering, zat perekat harus cukup kelenturannya, tidak rapuh dan kaku

5) Tahan terhadap serangan jamur

6) Tidak mengandung alum 
7) Perekat alami harus dapat dibuka dengan merendam dalam air, perekat sintetik harus dapat larut dalam pelarut tertentu (Perka Anri Nomor 23 Tahun 2011).

\section{Tahapan Perbaikan}

Menurut Perka ANRI nomor 23 Tahun 2011, hal-hal yang perlu diperhatikan dalam tahapan perbaikan adalah:
a. Penerimaan arsip yang akan diperbaiki
b. Pemotretan sebelum perbaikan untuk melihat kondisi sebelum diperbaiki
c. Penomoran lembaran arsip agar tidak hilang atau berantakan
d. Pemeriksaan kondisi arsip
e. Pembersihan arsip dapat menggunakan dust vacuum, air gaun atau sikat:

1) Untuk menghilangkan noda yang melekat pada arsip kertas dan sulit dihilangkan dapat digunakan pelarut organik, sedangkan noda karena cat dan minyak dapat dihilangkan dengan benzene

2) Sellotep yang digunakan sebagai perekat pada arsip kertas harus dihilangkan karena bahan perekat pada sellotep dapat merusak kertas. Biasanya kertas akan berubah warna menjadi kuning kecoklatan pada daerah yang menempel dengan sellotep. Perekat pada sellotep tidak larut dalam air, oleh sebab itu plastic pada sellotep harus dilepas dengan pelarut organik. Pertama dicoba dengan heptana atau benzene, jika tidak berhasil dicoba lagi dengan pelarut lain seperti toluene, aseton, atau etil alcohol. Percobaan harus dilakukan pada areal yang kecil (pada satu titik) dan kertas yang akan dibersihkan diletakkan di atas kertas penyerap bebas asam, caranya bagian bawah dari kertas yang ada sellotape-nya dibasahi dengan pelarut organik dengan bantuan kapas, ditunggu beberapa detik kemudian kertas dibalik. Plastik sellotape diangkat dengan scalpel atau jarum dan ditarik ke belakang dengan hati-hati. Bila perlu dilunakkan lagi perekat tersebut untuk mempermudah pekerjaan. Hilangkan bahan perekat yang masih ada dengan kapas yang dicelupkan ke dalam pelarut organik.

f. Penentuan metode restorasi yang akan digunakan 
g. Membuat laporan dokumentasi fisik arsip (kondisi arsip, metode perbaikan, tanggal staf yang memperbaiki).

h. Deasidifikasi

Deasidifikasi adalah cara untuk menetralkan asam pada kertas yang dapat merusak kertas dan memberi bahan penahan (buffer) untuk melindungi kertas dari pengaruh asam yang berasal dari luar. Proses deasidifikasi dilakukan melalui 2 (dua) cara yaitu:

1) Cara basah

Cara basah tidak dapat digunakan pada arsip yang sensitif/rapuh terhadap air dan tinta yang larut dalam air. Cara ini hanya dilakukan pada arsip yang tunggal dan tidak untuk arsip berjilid kecuali arsip dipisahkan satu sama lain kemudian disatukan lagi. Bahan kimia yang digunakan antara lain kalsium karbonat. Jika menggunakan kalsium karbonat, konsentrasinya adalah $0,1 \%(w / v)$. Caranya, arsip direndam selama 30 menit lalu diangkat dan dikeringkan. Selain menggunakan bahan kimia tersebut, mencuci dengan air juga dapat menghilangkan asam pada arsip kertas tetapi tidak dapat melindungi kertas dari pengaruh asam dari luar.

2) Cara Kering

Cara kering digunakan untuk arsip kertas dengan tinta yang larut dalam air dan dapat digunakan untuk arsip yang berjilid karena gas atau pelarutnya dapat masuk ke dalam celah arsip. Sebaiknya ruangan deasidifikasi cara kering dilengkapi dengan exhaust fan untuk melancarkan sirkulasi udara. Bahan kimia yang digunakan adalah bookkeeper/phytate yang berisi magnesium oksida dalam triklorotriflu roetan. Caranya dengan menyemprotkan larutan pada permukaan arsip kertas kemudian dikeringkan dan digantung atau dalam rak-rak. Sebelum disimpan, arsip harus dipastikan sudah benar-benar kering.

i. Tindakan perbaikan arsip

j. Melakukan pemotretan setelah perbaikan, untuk melihat kondisi setelah direstorasi

k. Membuat daftar arsip yang telah direstorasi. 


\section{Proses Perbaikan Arsip}

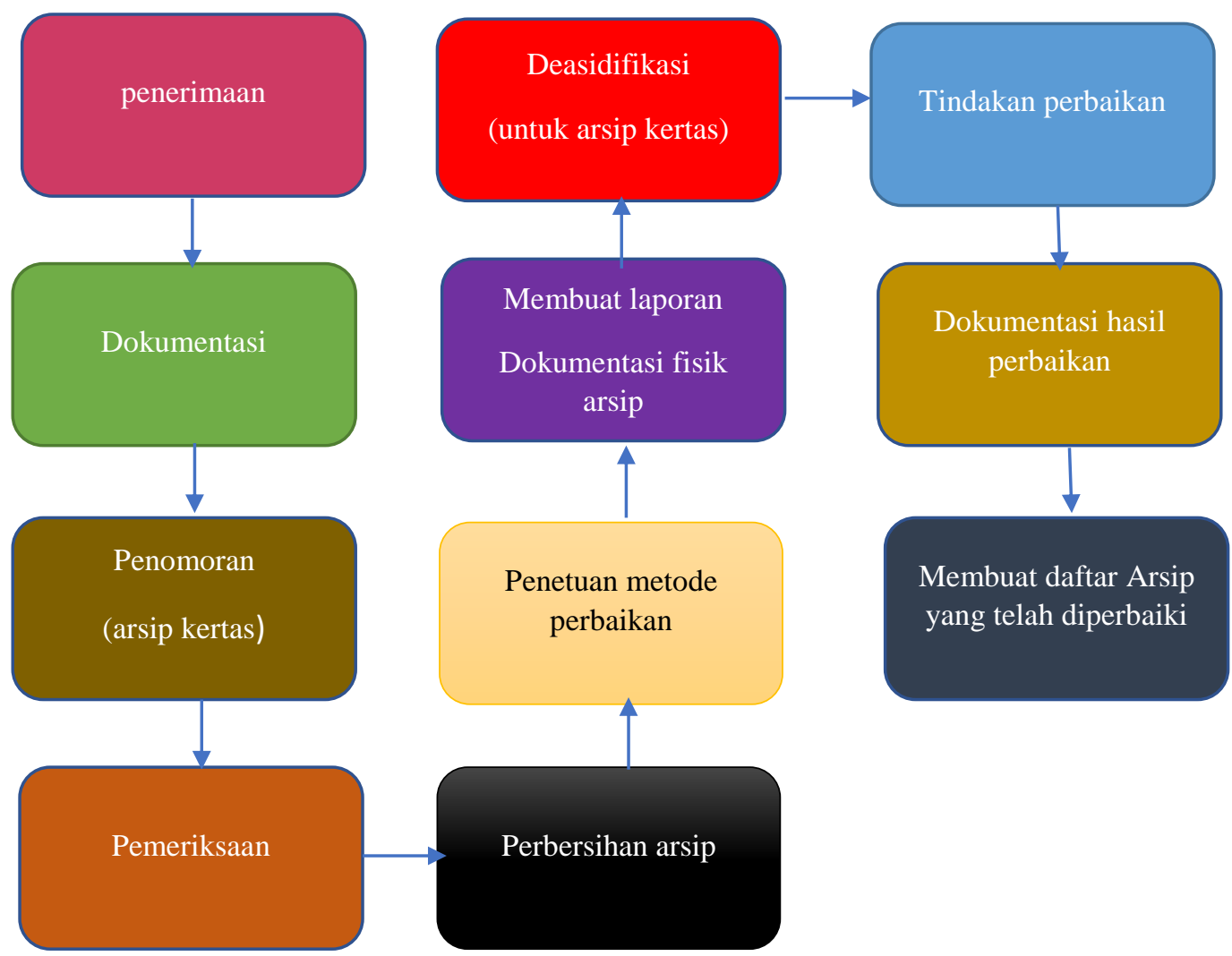

Gambar 1. Bagan Alur Proses Perbaikan (Restorasi) Arsip statis

Sumber: Perka ANRI Nomor 23 Tahun 2011

3. Teknik Perbaikan

Dalam Perka ANRI Nomor 23 Tahun 2011 menjelaskan, ada beberapa hal yang terdapat dalam teknik perbaikan, yaitu:

a. Menambal dan menyambung secara manual

1) Menambal dan menyambung dilakukan untuk memperbaiki bagianbagian arsip yang hilang dan berlubang akibat bermacam-macam faktor perusak

2) Metode ini umumnya dilakukan untuk arsip yang kerusakannya relatif sedikit/jumlah arsip sedikit

3) Menambal dan menyambung dilakukan melalui beberapa cara yaitu:

a) Menambal dan menyambung dengan bubur kertas

b) Menambal dengan potongan kertas

c) Menyambung dengan kertas tisu

d) Menambal dengan kertas tisu berperekat 


\section{b. Leafcasting}

1) Bagian-bagian arsip yang hilang dan berlubang dapat diperbaiki melalui kegiatan leafcasting

2) Metode ini tidak dianjurkan untuk arsip kertas dengan tinta yang luntur

3) Prinsip metode ini adalah perbaikan melaui proses mekanik menggunakan suspense bubur kertas (pulp) dalam air, yang dihisap melalui screen sebagai penyangga lembaran kertas sehingga bagian yang hilang dari lembaran kertas dapat diisi dengan serat selulosa

c. Paper Spliting dan Sizing

1) Metode paper splitting adalah metode perbaikan arsip kertas yang rapuh dengan cara:

a) Menyelipkan kertas penguat (tisu) di antara bagian permukaan dan belakang arsip kertas

b) Melakukan sizing, yakni memberikan lapisan dengan bahan perekat atau bahan pengisi

2) Cara pembuatan bahan bahan perekat untuk sizing (campuran starch dan methyl cellulose (MC) dengan perbandingan 2:1):

a) Sebanyak 150 gram starch dilarutkan dalam $400 \mathrm{ml}$ air dingin dan kemudian ditambahkan air panas hingga volume menjadi $2000 \mathrm{ml}$ sambil diaduk (campuran A), kemudian dinginkan

b) Sebanyak 75 gram methyl cellulose dilarutkan dalam $2000 \mathrm{ml}$ air, diaduk dengan pengaduk (mixer) hingga larutkan homogen (campuran B)

c) Kemudian campuran A dan B diaduk dengan pengaduk (mixer) hingga homogen, dan siap digunakan

\section{d. Enkapsulasi}

1) Enkapsulasi adalah salah satu cara perbaikan arsip kertas yang rapuh dan sering digunakan dengan bahan pelindung untuk menghindarkan dari kerusakan yang bersifat fisik

2) Arsip yang dienkapsulasi umumnya adalah kertas lembaran seperti naskah kuno, peta, bahan cetakan atau poster 
3) Enkapsulasi dilakukan dengan cara setiap lembar arsip dilapisi oleh dua lembar plastik polyester dengan bantuan double tape

4) Prosedur pelaksanaan enkapsulasi adalah:

a) Memilih arsip yang membutuhkan bahan pelindung dari kerusakan

b) Membersihkan setiap lembar arsip kertas dari debu dan kotoran:

1. Yang menempel pada arsip dihapus menggunakan sikat halus/kuas, kemudian kotoran disapu dari arah tengah arsip menuju bagian tepi dan dilakukan searah untuk menjaga arsip tidak sobek atau mengerut

2. Yang melekat kuat pada arsip dihapus menggunakan karet penghapus, kemudian kotoran disapu menggunakan kuas

3. Bersihkan debu dan kotoran yang terlepas dari arsip

c) Siapkan dua lembar plastik polyester dengan ukuran kira-kira 2,5 cm lebih panjang dan lebih lebar dari arsip

d) Tempatkan plastik polyester di atas kaca atau karet magic cutter dan bersihkan dengan kain lap

e) Menempatkan arsip yang akan dienkapsulasi di atas plastik polyester dan letakkan pemberat pada bagian tengah arsip

f) Berilah perekat double tape kira-kira $3 \mathrm{~mm}$ dari bagian pinggir arsip dan beri celah kecil pada setiap sudutnya. Perekat double tape tidak boleh menempel pada arsip karena dapat merusak arsip

g) Tempatkan plastik polyester penutup di atas arsip dan letakkan pemberat pada bagian tengah arsip tersebut

h) Lepaskan lapisan kertas pada double tape di bagian A dan B

i) Gunakan roll atau wiper dan tekan secara diagonal untuk mengeluarkan udara dari dalam dan untuk merekatkan double tape pada plastik polyester

j) Lepaskan sisa kertas dari double tape pada bagian sisi C dan D dan gunakan roll untuk merekatkan double tape pada keempat sisi 
k) Potong plastik yang berlebih, kira-kira 1-3 $\mathrm{mm}$ dari pinggir bagian luar double tape. Pemotongan dapat dilakukan dengan kacip atau menggunakan cutter dan penggaris besi

1) Potong bagian sudut enkapsulasi menggunakan hook cutter dan gunting kuku sehingga bentuknya agak bundar

m) Proses enkapsulasi dapat dilihat pada gambar di bawah ini

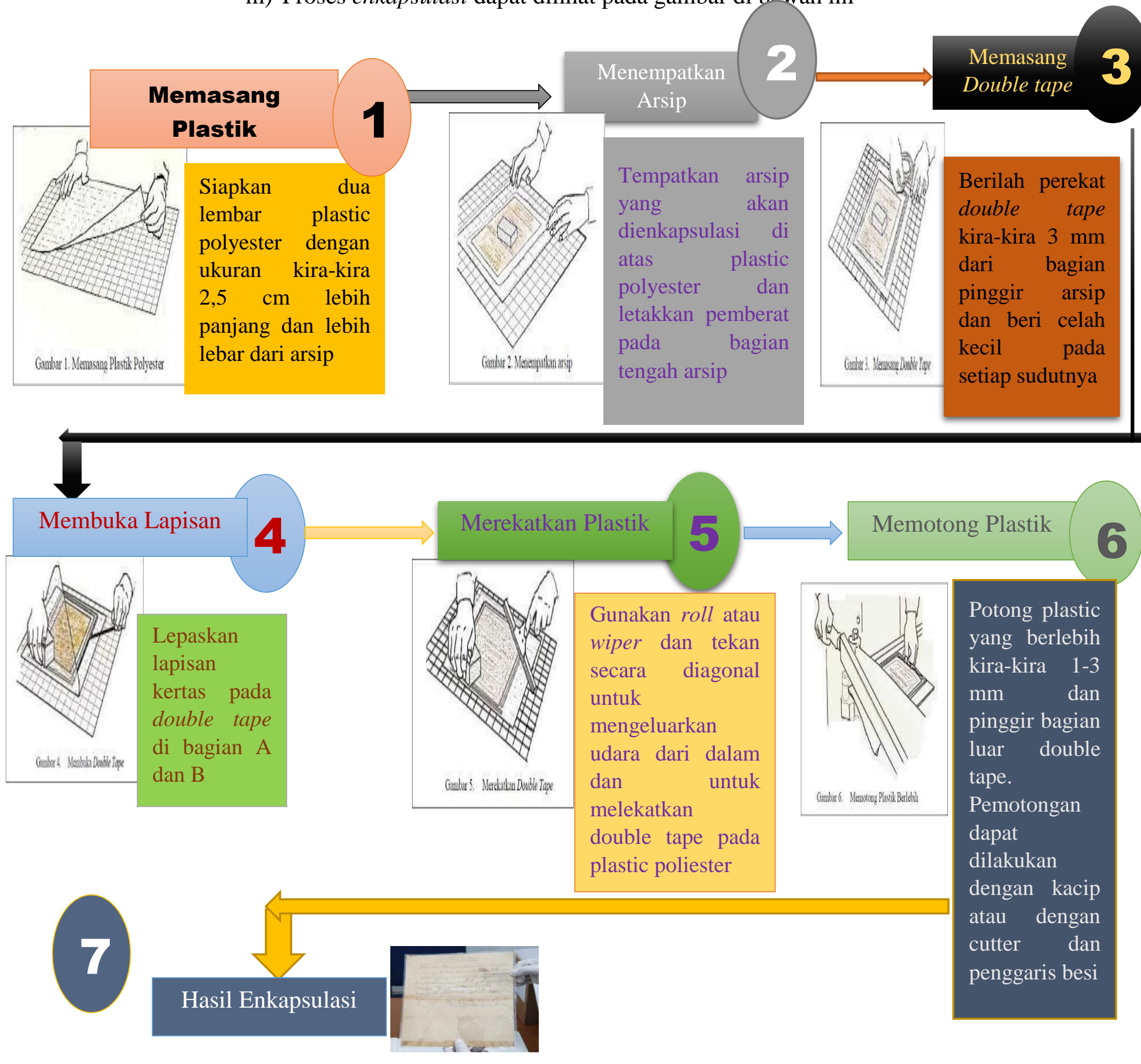

Potong bagian sudut enkapsulasi dengan menggunakan hook cutter/gunting kuku sehingga bentuknya agak bundar
Gambar 2. Proses Enkapsulasi

Sumber Perka ANRI Nomor 23 Tahun 2011 
e. Penjilidan dan Pembuatan Kotak Pembungkus Arsip

1) Penjilidan adalah menghimpun lembaran-lembaran lepas arsip menjadi satu dan dilindungi dengan ban/sampul

2) Penjiidan juga dapat dilakukan pada arsip yang berbentuk buku/jilidan yang mengalami kerusakan lem, jahitan terlepas, lembar pelindung atau sampul terlepas, atau sobek

3) Arsip berupa lembaran lepas (tidak akan dilakukan penjilidan) dengan kondisi rusak parah), dibuatkan kotak pembungkus arsip supaya tidak tercecer atau terlindung dari faktor perusak dari luar

4) Prosedur pembuatan kotak pembungkus arsip adalah:

a) Ambil papan (board) dan potong sesuai dengan ukuran yang diinginkan, dengan tambahan lebar dan panjang 2-3 cm dari dokumen yang akan disimpan, buat sebanyak 2 lembar

b) Lapisi atau tempel dengan kertas yang bebas asam dan bebas lignin dengan lem

c) Setelah lem kering, buat lubang pita dengan pahat dan dibuat agak sedikit longgar supaya pita dapat bergeser dengan baik

d) Lubang pita dibuat pada $1 / 4$ bagian panjang papan (board) dan $1,5 \mathrm{~cm}$ dari sisi atau pinggir, sebanyak 4 buah masing-masing pada lembar papan

e) Masukkan pita ke dalam lubang-lubang (biasanya panjang pita kirakira 25-30 cm) (Sattar, 2020).

f. Perbaikan Arsip Peta

Perbaikan arsip peta dapat dilakukan dengan beberapa cara yaitu:

1) Perbaikan arsip peta dengan cara Lamatex Cloth

Perbaikan arsip peta dilakukan dengan menggunakan bahan lamatex cloth yaitu kain berperekat yang apabila terkena panas tertentu di atas $700^{0} \mathrm{c}$ akan menempel. Cara perbaikan peta dengan bahan lamatex cloth tersebut dilakukan untuk peta yang informasinya hanya terdapat di satu permukaan peta saja.

Proses perbaikan dengan metode lamatex cloth adalah: 
a) Semua tambalan atau sellotape yang terdapat di belakang maupun di depan arsip peta dilepas

b) Letakkan peta yang akan diperbaiki di atas meja mounting

c) Potong bahan lamatex cloth yang akan digunakan sesuai dengan ukuran peta yang akan diperbaiki

d) Buka lamatex cloth dari lapisan kertas lilin yang menempel

e) Letakkan peta di atas lamatex cloth yang telah dibuka lapisannya

f) Agar peta tidak bergerak pada saat diperbaiki, maka letakkan pemberat di atas peta

g) Gunakan solder atau setrika untuk merekatkan sementara antara peta dengan lamatex cloth pada beberapa sudut peta

h) Rapikan tepi lamatex cloth yang tersisa dengan memotongnya dan sisakan dengan lebar $1,5 \mathrm{~cm}$ untuk membuat bingkai

i) Buat bingkai pada tepi peta dengan melipat tepi lamatex cloth ke dalam sehingga menjadi lipatan selebar $1 \mathrm{~cm}$

j) Sudut-sudut lamatex cloth dipotong seperti huruf v kemudian dilipat sehingga membentuk sudut siku

k) Pres peta pada mesin pres panas dengan temperatur $70^{\circ} \mathrm{C}-80^{\circ} \mathrm{C}$, dilapisi kertas silicon, selama kurang lebih 30 detik

1) Angkat peta dari mesin pres, kemudian semua bagian pinggir bingkai peta dipotong $0,5 \mathrm{~cm}$ dari tepi peta

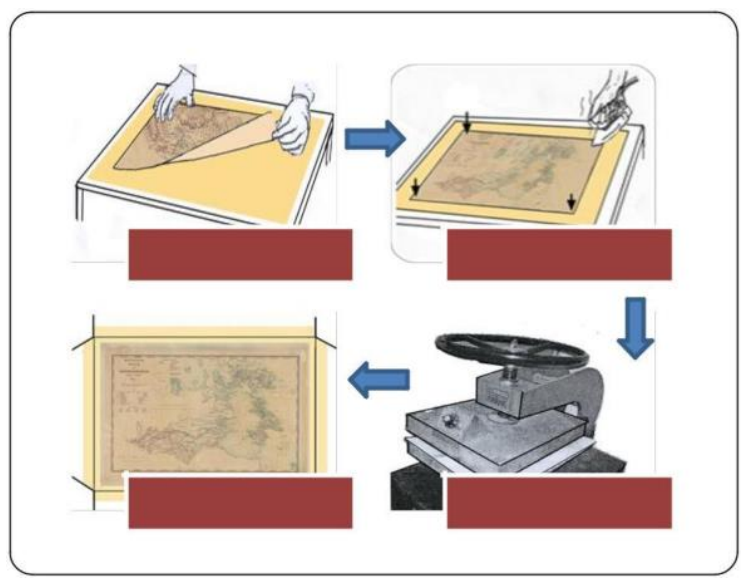

Gambar 3. Perbaikan Arsip Peta dengan Lamatex Cloth Sumber: Perka ANRI NOmor 23 Thaun 2011 
2) Perbaikan Arsip Peta dengan cara tradisional

Perbaikan arsip peta dilakukan untuk arsip peta yang masih kuat tintanya (tinta tidak luntur terkena air) dan kondisi fisik peta masih kuat. Kertas conqueror digunakan sebagai bahan penguat di bagian belakang arsip peta dan kertas handmade digunakan sebagai bingkai pada pinggir peta bagian depan.

Cara kerjanya adalah:

a) Siapkan arsip peta yang akan diperbaiki dan dialasi dengan plastic astralon

b) Cuci arsip peta hingga bersih dengan air hangat dan ditiriskan

c) Siapkan kertas conqueror sesuai ukuran peta yang akan diperbaiki, lalu basahi dengan larutan kalsium karbonat $0,1 \%$ (w/v) dan alasi dengan plastic astralon

d) Siapkan kain sutra (tisu) lalu lekatkan di atas mika. Kertas conqueror diberi lem encer (starch) dan letakkan di atas sifon (trylin), kemudian ratakan

e) Bagian atas conqueror diolesi lem kental, begitu pula bagian belakang peta

f) Peta diletakkan di atas kertas conqueror, dan kemudian direkatkan perlahan-lahan

g) Setelah rata, bagian pinggir peta dibingkai dengan menggunakan kertas $1 \mathrm{~cm}$ dari bagian tepi peta

h) Seluruh permukaan peta di sizing dengan menggunakan lem encer

i) Peta kemudian dikering-anginkan kurang lebih 24 jam di ruang ber$\mathrm{AC}$

j) Setelah kering, bagian pinggiran peta dirapikan (Sattar, 2020)

\section{B. Perawatan Arsip Audiovisual}

1. Arsip Foto

Arsip foto menurut Herman dalam Amalia Husna Radliani adalah arsip yang isi informasinya terekam dalam bentuk gambar static berupa citra diam/tidak bergerak dimana informasinya adalah citra yang terbentuk 
melalui proses pencahayaan terhadap bahan berlapis kimia dan merupakan alat visual yang efektif karena dapat memvisualisasikan sesuatu dengan lebih konkret, realistis dan lebih akurat serta bersifat unik karena menggambarkan sesuatu dengan apa adanya tanpa rekayasa (Setyawan, 2010). Untuk memelihara arsip foto khususnya negatif foto yang kotor atau berjamur dilakukan dengan pembersihan menggunakan negative cleaner (film cleaner) misalnya isopropanol, hidrofluoroeter dengan cara menggosok searah secara perlahan dengan kain halus (Sattar, 2020).

2. Arsip Film

Menurut Perka Anri No 23 Tahun 2011, Arsip film adalah arsip yang isi informasinya berupa citra bergerak (moving image), terekam dalam rangkaian gambar foto grafik dan suara pada bahan dasar film, yang penciptaannya menggunakan rancangan teknis dan artistik dengan peralatan khusus.

a. Sebelum arsip film dilakukan perawatan, harus dilakukan identifikasi (inpeksi) terhadap kondisi arsip film. A-D strips atau indicator bromocresol dapat digunakan untuk mendeteksi kerusakan yang terjadi pada arsip film.

b. Arsip film berbahan dasar asetat yang mulai rusak ditandai dengan adanya bau seperti cuka atau bau kapur barus. Sedangkan kerusakan karena air menyebabkan film yang melengkung atau kehilangan emulsi. Selain itu efek lain yang ditimbulkan adalah ferrotyping, blocking dan jamur

c. Arsip film yang rusak karena terputus digunakan splacer baik dengan splacing tape atau film cement untuk base film acetate. Film cement mengandung pelarut yang dapat melarutkan base film dan apabila mengering akan menyatukan dua potongan film

d. Pemeliharaan arsip film dilakukan dengan membersihkan film dari kotoran, lemak dan residu kimia yang membahayakan dari permukaan film

e. Membersihkan fisik film dapat dilakukan dengan beberapa cara di antaranya: 
1) Cleaning film dengan menggunakan pelarut (solvent). Pelarut yang digunakan dapat merupakan pelarut organik (hidrokarbon) dan pelarut air (dicampur dengan surfaktan). Pelarut organik yang umum digunakan adalah 1,1,1 trichloroethane. Namun, bahan ini bersifat merusak ozon, sebagai alternatif pengganti dapat digunakan isopropyl alcohol.

2) Rewashing Film

Rewashing dilakukan untuk mengurangi noda pada permukaan film seperti akibat goresan kecil, efek ferrotyping dan jamur. Namun rewashing film ini dimungkinkan memiliki kelemahan yaitu dapat melemahkan base film, merusak perforasi dan splices, larutannya emulsi dan image dyes.

3) Unblocking

Larutan unblocking digunakan untuk mengendurkan dan melepaskan film yang terkena blocking (jika film base terdekomposisi melalui mekanisme vinegar syndrome). Untuk film dengan block yang menyebabkan kerusakan pada base dapat digunakan larutan etanol

4) Dry Cleaning

Metode dry cleaning digunakan untuk mengatasi arsip yang terkena vinegar syndrome. Caranya adalah dengan melepaskan film dari gulungan, kemudian disimpan di suatu tempat tertentu untuk dikeringkan-anginkan. Ruangan yang digunakan sebaiknya bebas dari debu dan terhindar dari cahaya matahari langsung. Jika menggunakan ruangan tertutup, sebaiknya menggunakan blower fan untuk membantu mempercepat pengeringan (Sattar, 2020).

3. Arsip Video

a. Pemeliharaan dan perlindungan arsip video diutamakan pada kualitas gambar dan suara. Pendeteksian kerusakan dilakukan dengan alat khusus yang dapat menilai kerusakan pada gambar dan suara secara tepat dengan menampilkan lokasi kerusakan.

b. Video dapat dibersihkan dengan mesin (video cassette evaluator/cleaner). Videocassette evaluator/cleaner dapat bekerja secara 
otomatis untuk memeriksa fisik video tape, seperti: akibat kerutan, kusut dan kerusakan bagian tepinya, juga untuk membersihkan tape dari jamur sepanjang garis lintang tape

c. Jika pada tape terdapat residu bahan kimia yang lengket, maka tape perlu dibersihkan menggunakan kertas gosok berwarna putih berserat Panjang yang disebut pellon atau dengan atau dengan menggunakan tape cleaner.

4. Arsip Rekaman Suara

a. Pemiliharan Arsip rekaman suara dapat dilakukan melalui proses reklamasi

b. Reklamasi adalah proses dalam perolehan sinyal suara akibat deteriorasi atas kerusakan rekaman aslinya. Proses reklamasi merupakan perbaikan secara manual, termasuk pengopian secara elektronik yang dapat menghilangkan banyaknya suara (bising) yang tidak diinginkan

c. Reklamasi meliputi:

1) Pengurangan suara (bising) yang berlebihan, seperti "crackle" yang dijumpai dalam replaying rekaman fonografik yang tua

2) Pengeditan secara tepat terhadap bunyi letupan dan bunyi ceklekan yang tidak diinginkan

3) Ekualisasi untuk memperoleh tingkat frekuensi sinyal yang seimbang berdasarkan tinggi rendahnya frekuensi sinyal

d. Perawatan tape yang digunakan yaitu pembersihan tape seharusnya digunakan sebagai usaha terakhir bila head telah usang atau rusak

e. Pembersihan tape sebaiknya menggunakan swab (kain) penyeka isopropanol

\section{Metode Pengendalian Hama}

Hama perusak arsip adalah serangga, tikus, jamur atau organisme hidup lainnya yang berpotensi merusak arsip baik nilai fisik maupun informasinya. Pengendalian terhadap hama perusak arsip dapat dilakukan dengan cara (Perka ANRI Nomor 23 Tahun 2011):

1. Penggunaan Bahan Kimia 
a. Fumigasi merupakan suatu tindakan terhadap hama atau organisme yang dapat merusak arsip dengan pengasapan yang bertujuan mencegah, mengobati, dan mensterilkan bahan kearsipan, dengan menggunakan senyawa kimia yang disebut fumigant di dalam ruang yang kedap gas udara pada suhu dan tekanan tertentu. Mencegah dimaksudkan supaya kerusakan lebih lanjut dapat dihindari. Mengobati berarti mematikan atau membunuh serangga, kuman dan sejenisnya yang telah menyerang dan merusak bahan Pustaka dan arsip. Mensterilkan berarti menetralisasi keadaan seperti menghilangkan bau busuk yang timbul dari bahan kearsipan, dan menyegarkan udara sehingga tidak menimbulkan gangguan atau penyakit

b. Fumigan adalah bahan kimia yang dalam tekanan dan suhu normal berbentuk gas dan bersifat racun terhadap makhluk hidup yang dapat mengakibatkan kematian

c. Fumigasi tidak dapat memberikan perlindungan terhadap serangan kembali hama (reinvestasi) yang mungkin akan timbul setelah fumigasi

d. Fumigasi hanya dapat dilakukan oleh teknisi fumigasi yang terlatih dengan baik dan bersertifikat sesuai dengan standar yang benar serta menggunakan peralatan keselamatan kerja standar (fumigation safety equipment)

e. Bahan kimia yang digunakan dalam fumigasi diantaranya ethylene oksida, methyl bromide, phosphine, sulphuryl fluoride, thymol cristal. Di antara bahan-bahan fumigasi tersebut disarankan menggunakan phospine (dosis 1-2 tablet per $\mathrm{m}^{3}$, waktu fumigasi selama 3-5 hari)

f. Selain fumigasi, dapat digunakan kapur barus (nepthalene ball) yang diletakkan dalam ruangan penyimpanan untuk mengusir serangga

\section{Penggunaan Non-Bahan Kimia}

Metode yang dapat digunakan berupa freezing dan modifikasi udara (Perka ANRI Nomor 23 Tahun 2011):

a. Freezing, tidak dianjurkan untuk arsip yang sudah rapuh. Arsip seharusnya disimpan dalam pembungkus yang tertutup rapat untuk menghindari serangga keluar. Arsip dibekukan pada suhu $-29^{\circ} \mathrm{C}$ selama 
72 jam atau pada suhu $-20^{\circ} \mathrm{C}$ selama 48 jam. Seperti pada perlakuan fumigasi, jika arsip dikembalikan ke tempat penyimpanan yang tidak sesuai, maka reinvestasi akan terjadi lagi.

b. Modifikasi udara dilakukan dengan mengatur kandungan udara yaitu menurunkan kadar oksigen, menaikkan kadar karbon dioksida, dan penggunaan gas gas inert, terutama nitrogen. Modifikasi udara ini dapat dilakukan dalam ruangan khusus atau wadah plastic dengan low permeability.

\section{KESIMPULAN}

Dari penjelasan di atas dapat disimpulkan bahwa preservasi kuratif merupakan upaya yang paling efektif dalam mendukung preservasi jangka panjang arsip statis. Preservasi kuratif bertujuan untuk melindungi fisik arsip agar tahan lama, menghindarkan kerusakan arsip sehingga kandungan informasinya dapat terjaga selamanya. Berbagai macam bahan, tahapan-tahapan perawatan dan perbaikan dalam preservasi kuratif sangat berguna untuk menjaga keselamatan dan kelestarian arsip statis. Preservasi kuratif sangat berperan dalam menjaga, melindungi, memperbaiki dan merawat arsip statis.

\section{DAFTAR PUSTAKA}

Arsip Statis. (2021). Retrieved from Arsip Universitas: http://arsip.upi.edu/arsipstatis/ Indonesia, R. (2009). Undang-undang Nomor 43 Tentang Kearsipan. Jakarta: Sekretariat Negara.

Maziyah, S. (2005). Metode Preservasi dan Konservasi Arsip. Semarang: Universitas Diponegoro.

Nazir, M. (2014). Metode Penelitian. Ghalia Indonesia: Jakarta.

Sattar. (2020). Manajemen Arsip Statis. Yogyakarta: Deepublish.

Setyawan, H. (2010). Panduan Pengelolaan Arsip Foto (untuk internal arsip Universitas Gadjah Mada dan prosedur penyerahan dari perorangan dan dari unit-unit kerja di lingkungan UGM). Yogyakarta: Arsip Universitas Gadjah Mada. 
Sofia Nurani, 1. c. (n.d.). Preservasi Kuratif Arsip Statis tekstual Pasca Bencana Alam Letusan Gunung Merapi Tahun 2010 Dalam Upaya Penyelamatan Arsip Di Dinas Perpustakaan dan Arsip Kabupaten Sleman. 2.

Sugiyono. (2016). Metode penelitian kuantitatif, kualitatif dan R\&D. Bandung: Alfabeta. 